\title{
EFFECT OF LEADERSHIP AND WORK ENVIRONMENT TOWARD ORGANIZATIONAL COMMITMENT WITH JOB SATISFACTION AS INTERVENING VARIABLES
}

\author{
Amrillah* \\ Master's Program in Management, University of Mataram, Indonesia \\ Suparman Lalu, Sulaimiah, Lecturers \\ Master's Program in Management, University of Mataram, Indonesia \\ ${ }^{*}$ E-mail: dmm amrillah@yahoo.co.id
}

\begin{abstract}
The aim of this study is to analyze and to know the significant effect of leadership, work environment to job satisfaction and organizational commitment of elementary school teachers in Batukliang subdistrict. The sample of this research are teachers with civil servant status (PNS) at education institution of elementary school in Batukliang sub-district spread over 45 elementary schools with 200 teachers (excluding school principals). Sampling technique in this research is using purposive sampling. Data analysis done using path analysis with Structural Equation Modeling with AMOS-20. The research results showed that leadership and work environment have a significant effect on satisfaction of elementary school teachers in Batukliang sub-district.
\end{abstract}

\section{KEY WORDS}

Leadership, work environment, job satisfaction, organizational commitment, teacher.

Staff's organizational commitment in several cases influenced by whether or not they satisfy with the salary, the job, the supervision quality and relation with other staff members. Sutrisno (2009) argue that job satisfaction is one of employee attitude that related to the working environment, cooperations between the staff members, amount of reward and psychological aspect during work. Sopiah (2008) conclude that job satisfaction can be identified as an emotional response of an employee towards the job and working condition. The emotional response could be formed in satisfaction or disappointment, if the employee is emotionally satisfied with their job then job satisfaction is achieved and vice versa. Job satisfaction could be achieved after their expectations and actual condition are compared. Furthermore, Robbins and Judge (2008) acknowledge that job satisfaction commonly driven by several factors such as; job desk, supervision, salary, promotion opportunity, and between employees relations.

On the other hand, according to Luthan (2006) job satisfaction can be measured by five indicators which are; the job itself, salary, promotion opportunity, supervision, and coworkers. An evaluation on link between job satisfaction and organizational commitment has been conducted by (Hidayat, 2013; Junaedi et al., 2013; Karim dan Rehman, 2012; Kurniasari dan Halim, 2013; Muhadi, 2007; Novriyadhi dan Riana, 2015; Parwita, 2013; and Retnaningsih, 2007); shows that job satisfaction correlates with the organizational commitment. While Saputra (2013) found that job satisfaction is the most dominant factors contribute to organizational commitment, interestingly evaluation done by Rahmi (2013) shows that job satisfaction positively correlate to organizational commitment but not giving significant impact. Manuel \& Rahyuda (2015) declare that organizational commitment could mediate between job satisfaction and turnover intention. Wirakusuma and Sintaasih, (2015) also stated that there are positive correlations between job satisfaction and organizational commitment with the employee's status as a variance. Tabitha and Harjanti, (2015); Santoso (2014) found that job satisfaction mediates the influence of leadership towards organizational commitment. Wirawan, (2013) found that whether or not an employee satisfies with the job affect the variables which mediate between job satisfaction an employee's performance. Whereas, Hidayat, (2013) found that there is an insignificant positive effect of leadership on 
job satisfaction. However, job satisfaction could not mediate influence between leadership towards organizational commitment. Rustini (2015) states that organizational commitment mediates the influence of the work environment on performance. Therefore, from the results of previous research there are still results of inconsistent research that needs to be studied further and have not found a study that examines the direct and indirect influence simultaneously the influence of leadership and work environment on organizational commitment with satisfaction as a moderation variable.

In the case of leadership related to job satisfaction and organizational commitment, Herzberg (in Wirawan, 2013) reveals that leadership is one factor that can affect job satisfaction. The results of this study are strengthened by (Junaedi and Utami, 2013; Muttaqien, 2014; Plangiten, 2013); leadership has a significant effect on job satisfaction. Several studies in other countries have shown that strong leadership impacts in schools, can create a change development (Hopkins 2001a, West et al., 2000). Meanwhile Hopkins (2001b) highlights the importance of transforming leadership and learning practices to achieve improvement in schools. However, according to a research conducted by Rahmi (2013), it shows leadership has a positive but insignificant effect on job satisfaction while leadership has a significant positive effect on organizational commitment. Whereas, Tabitha and Harjanti, (2015), declare that there is a significant influence of leadership on organizational commitment both directly and indirectly. For the working environment related to job satisfaction and organizational commitment, (Lutans, 2006; Kurniasari and Halim, 2013; Mincu, 2014; Nasution, 2013; and Plangiten, 2013), the results of the study show that the working environment has an effect on job satisfaction. in addition Akhtar (2014) stated that the working environment affects the job satisfaction and organizational commitment of employees. Empirical studies by Kurniasari and Halim (2013) also found that the working environment had an effect on organizational commitment. While Rustini (2015) found there was a positive influence of work environment on commitment, McGuire \& McLaren, 2009; and Saputra, 2013), argue that there is a strong positive correlation between work environment and employee commitment.

Commitment issues could appear in various types of organizations, one of them in educational institutions. According to Law no. 14/2005, a teacher has a function, role, and position which is very strategic in national development in the field of education, which are an effort to educate nation life and improve quality of Indonesians. Who has competency in science, technology, and art in realizing a society that is advanced, fair, prosperous, and civilized. The teacher's duties and functions as mentioned above cannot be properly implemented if a teacher's commitment is infirm. In fact, in the Stated Elementary School (SDN) in Batukliang Subdistrict, Central Lombok, there are numerous problems related to teachers' commitment. These problems include, discipline teachers in running some rules have not been maximized as it can be seen from the teachers not following the working hours, some of them may come late to the school or go home early. Another indication of the declining commitment of teachers in some SDNs in Batukliang subdistrict is that school programs designed and created by the Principal along with teachers are have not well achieved, and some teachers' intent to move to other duty areas. Other problems found in the education environment of elementary school (SDN) in Batukliang sub-district are the problem of teacher work satisfaction, the principal leadership problem, and working environment problem. Some of the teachers interviewed expressed their dissatisfaction. Some teachers' dissatisfaction with their own work, colleagues, and the principal's style of leadership. This study aims to analyze and assess the significance of the influence of leadership, work environment to satisfaction and work commitment of teachers either directly or indirectly through job satisfaction as a moderation variable.

\section{LITERATURE REVIEW}

Leadership. Herzberg (in Wirawan, 2013) explain numbers of factors that affect job satisfaction are work, working conditions, work environment, job securities, compensation, health insurance, career path, organizational policy, leadership, subordinate employee 
relations, coworkers relationship, autonomy work, and rewards. According to Luthans (2006), supervision from the boss is a crucial point that contributes to job satisfaction. Luthans further explained that for now there are two dimensions of supervisory style that affect satisfaction that is centered on employees and the dimension of participation or influence. Muttaqien, (2014) in his research found that leadership has a significant effect on employee job satisfaction. As well as Plangiten (2013) found that leadership style affecting employee job satisfaction. Junaedi et al., (2013) also found leadership has a significant effect on job satisfaction. The results of Tabitha and Harjanti (2015) research shows that job satisfaction mediates the influence of leadership style on organizational commitment. However, Rahmi (2013) shows that transformational leadership has a positive but insignificant effect on job satisfaction.

In line with Rahmi, Hidayat's research (2013) also shows there is a direct positive but insignificant correlation of leadership on job satisfaction. Job satisfaction does not mediate the influence of leadership on organizational commitment. Brenninkmeyer \& Spillane (2008) in a recent study stated that the main task of a leader is to spend a lot of time solving learning problems at school, and solving performance-related problems. The real effect can be seen on student outcomes at school, and the school becomes effective. Therefore it takes a leader who not only determines direction but they also have consistent value and practice (Sergiovanni, 1995).

$\mathrm{H}_{1}$ : leadership has a positive and significant impact on job satisfaction.

Luthans (2006) stated that working conditions have an influence on job satisfaction. If the conditions are good (eg. clean and pleasant environment), individuals will be easier to complete their work. In contrary, in lousy working conditions (eg hot air, noisy environment), individuals will be difficult to complete their work. Luthans further explained, lately because of the diversity of the workforce that increased working conditions become important. Working environment effects on job satisfaction as well as workgroup effects. If the working environment is great then there will be no problem on job satisfaction, and vice versa if the work environment is bad then it will cause problems of job dissatisfaction. Herzberg (1959, in Wirawan, 2013) as has been expressed above the factors that may affect job satisfaction such as working conditions, work environment, subordinate boss relationships, and coworkers relationship. Kurniasari and Halim (2013) found that the working environment affects the job satisfaction. The results of Plangiten (2013) shows that the working environment has an effect on employee job satisfaction. Nasution (2013) in his research found that the working environment affects the job satisfaction. Research by Mincu (2014) also provides a conclusion that is similar to Nasution is the work environment in an organization affect the job satisfaction.

$\mathrm{H}_{2}$ : Work environment has a positive and significant impact on job satisfaction.

Organizational commitment is the willingness of individuals to remain together in an organization to achieve the goals set. Individuals who have high organizational commitment will always be loyal to the organization and try to make efforts to build the organization (Gholi pour, 2012). Wirawan (2013) argue that one of the outcomes of leadership in an organization is the organizational commitment of his followers. Furthermore, Wirawan said that if the follower's commitment to the organization is high, they will provide a great quality of working performance. Commitments according to Luthans (2006), are determined by the person's variables (age, position in organization, and dispositions such as positive or negative effectiveness, or internal or external control attribution), organization (job design, value, support, and supervisory leadership style); non-organizational factors such as the existence of other work alternatives. The results of Tabitha and Harjanti (2015) found that leadership style has a positive and significant effect on organizational commitment either directly or indirectly through job satisfaction. Hidayat's research (2013) found a significant direct and positive influence of leadership on organizational commitment. There is a significant indirect and positive influence of leadership on organizational commitment with organizational communication intervention. There is a positive but insignificant indirect influence of leadership on organizational commitment with job satisfaction interventions. There is a positive and significant indirect influence of leadership on organizational commitment with 
organizational communication interventions and job satisfaction. A study conducted by Santoso (2014) found that leadership style has a significant influence on organizational commitment, leadership style has a significant influence on organizational commitment with job satisfaction as intervening variable. Rahmi (2013) found transformational leadership to have a positive and significant impact on organizational commitment. Retnaningsih's research results (2007) support the results of previous research. The results of his research found leadership has a positive and significant impact on organizational commitment. While research Junaedi et al., (2013) does not support some previous research results. The results of Junaedi and Utami (2013) show that leadership has no significant effect on organizational commitment.

$\mathrm{H}_{3}$ : leadership has a positive and significant impact on organizational commitment.

According to Kurniasari and Halim (2013) research outcome, the working environment measured through office design indicator, job equipment design, lighting, temperature and air conditioning, noise, leadership style, trust issues and authorization in a job description and decision making have an effect on organizational commitment. This means the working environment is one of the factors that determine the organizational commitment of employees. The result of Kurniasari and Halim research is in line with the research that has been done by Saputra (2013), it shows that the working environment has a significant effect on organizational commitment. While Rustini (2015) found there was a positive influence of work environment on budget management commitment. The result of Rustini's research also shows that organizational commitment mediates the influence of the working environment on the performance of budget managers. On the other hand, research conducted by McGuire and McLaren (2009) found a strong positive correlation between employee commitment and two independent variables (working area and working surface height), employee well-being fully mediates the influence of the physical environment on employee commitment and relationships a strong positive between the physical environment and employee commitment.

$\mathrm{H}_{4}$ : the work environment has a positive and significant impact on organizational commitment

Organizational commitment reflects the individuals perceive of an organization and engaged in the organization goals (Wibowo, 2010). Wibowo further explained that the increasing the commitment of senior staff members may rise employee's job satisfaction. An institutional commitment can be used to predict variables associated with the organization such as turnover, staff's behavior, job satisfaction and performance (Wirawan, 2013). In addition, Wirawan (2013) sets out whether the employee's satisfaction with their work affects the mediation variables between job satisfaction and job dissatisfaction with employee performance and organizational performance. The mediation variables according to Herzberg (in Wirawan, 2013), are motivation, institutional commitment, absence, staff's behavior, industrial relations conflicts, work load, physical illness, psychological illness, interpersonal communication, withdrawal, and complaints.

Karim and Rehman (2012) in a study of employees in the Pakistani Civil Aviation Authority found that job satisfaction significantly affected organizational commitment. Saputra's research results (2013) also support previous research and concluded that job satisfaction has a significant impact on the organization's commitment. Novriyadhi and Riana (2015), Men and Authority (2015), Kurniasari and Halim (2013), Hidayat (2013), Junaidi et al., (2013), have similar results, job satisfaction having a positive influence on organizational commitment. A number of studies that explained above have a collateral result with research carried out by Retnaningsih (2007), Muhadi (2007), and Parwita (2013) that job satisfaction influence to institutional commitment. Manuel research and Rahyuda (2015) one of his findings is an emotional commitment, a calculative commitment, and has a normative commitment to intervene a role between the influence of job satisfaction on the intention of turnover. Wirakusuma and Sintaasih (2015) found a positive influence between job satisfaction and institutional commitment to employment status has the influence of moderation. Tabitha and Harjanti (2015) found that satisfaction in a mediation post influenced guidance on organizational commitment. The study found that job satisfaction had a positive and significant impact on the organization's commitment. Research conducted by 
Santoso (2014) found that job satisfaction mediates the influence of leadership on organizational commitment. Although Rahmi's research (2013) gives different results with previous research. One of the findings of Rahmi's research is that job satisfaction has a positive but inadequate impact on the organization's commitment.

$\mathrm{H}_{5}$ : job satisfaction has a positive and significant impact on the organization's commitment

$\mathrm{H}_{6}$ : leadership has a positive and significant impact on organizational commitment through job satisfaction.

$\mathrm{H}_{7}$ : leadership has a positive and significant impact on organizational commitment to job satisfaction.

\section{METHODS OF RESEARCH}

Quantitative approach is used to identify causal relationships (causal associative) and in this study there are independent variables, namely variables affect and the dependent variable is influenced variable (Sugiyono, 2010). The independent variables are principal leadership and work environment, the dependent variable is teacher commitment and job satisfaction as intervening variable. The sample of this research is civil servant teachers in Elementary School, Batukliang Central Lombok as many as 200 respondents. Methods of data collection using census method. The data collection tool uses questionnaire scale likert point 1-5 (Strongly Disagree to Strongly Agree). The data analysis technique using Structural Equation Modeling (SEM).

This study adopted the leadership indicator of Rivai (2010) with 7 statement items. For work environment indicators, researchers adopted from research conducted by Sedarmayanti (2011), Wursanto (2005), Matin \& Fuad (2016). Job satisfaction indicator using item statement from Luthans research (2006). And indicators of organizational commitment using as many as 13 items statement from research conducted by Meyer \& Allen (in Wirawan, 2013). Here is the conceptual model of research:

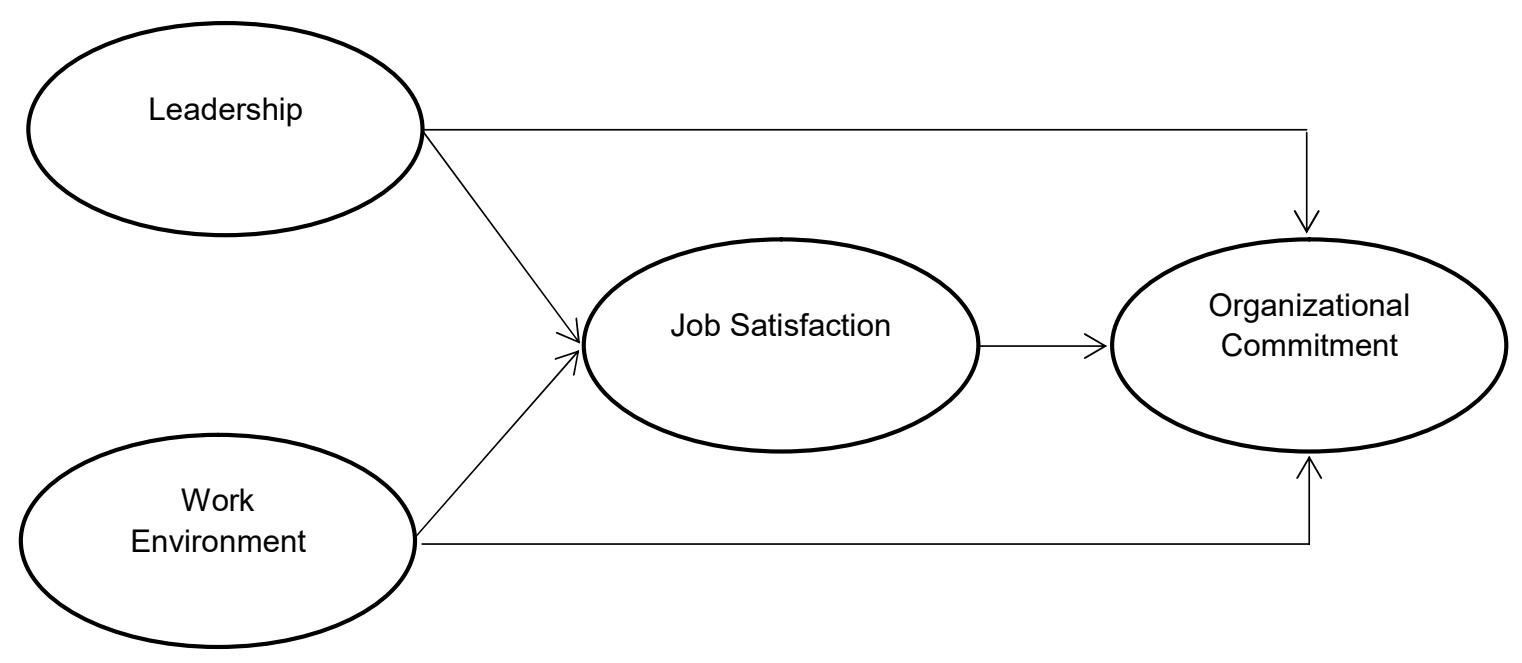

Figure 1 - Conceptual Framework

\section{RESULTS AND DISCUSSION}

In this study, data analysis obtained based on the characteristics of respondents as much as 200 teachers. Results of data analysis obtained on the characteristics of respondents, among others by gender, age, term of office, and class. For more details data on the classification of respondents can be seen in table 1.

Based on table 1 shows the characteristics of respondents by sex more dominated by men with age range above 50 years, duration of ten years over 30 years and the majority are in class IV. 
Table 1 - Characteristics of respondent

\begin{tabular}{llll}
\hline \multirow{2}{*}{ Respondent characteristics } & Amount (person) & Percentage (\%) \\
\hline Gender & Male & 124 & 62.0 \\
& Female & 76 & 38.0 \\
Age (years) & Total & 200 & 100 \\
& $<35$ years & 13 & 6.5 \\
& $36-50$ years & 66 & 33.0 \\
Term of office & $>50$ years & 121 & 60.5 \\
& Total & 200 & 100 \\
& $<10$ years & 45 & 22.5 \\
& $11-20$ years & 18 & 9.0 \\
Position class & $21-30$ years & 26 & 13.0 \\
& $>30$ years & 111 & 55.5 \\
& Total & 200 & 100 \\
& III & 38 & 19.0 \\
& III & 44 & 22.0 \\
& IV & 118 & 59.0 \\
\hline
\end{tabular}

Source: research result.

Validity test is done by CFA (Confirmatori Factor Analysis) test. The value of convergent validity can be seen from the loading factor of each variable studied, in the research the loading factor value for all items of the indicator is above 0.40 , the result refers from the opinion (Ferdinand, 2014) that the loading factor value must be greater than 0.40 . For discriminant validity can be known if the average difference or Square Root (SQRT) Average Variance Extracted (AVE) of the variables studied is greater than the latent variables (Forner and Larcker, 1981). The AVE value is used to test the square root of each AVE whether the correlation is greater than that of any latent construct. If SQRT AVE> quadratic correlation between constructs then it can be concluded that discriminant validity is acceptable.

Table 2 - Interrelated Correlation

\begin{tabular}{lllll}
\hline Variable & Leadership & Work Environment & Job Satisfaction & Organizational Commitment \\
\hline Leadership & 0,528 & & & \\
Work Environment & 0,052 & 0,553 & & \\
Job Satisfaction & 0,069 & 0,123 & 0,454 & \\
Organizational Commitment & 0,151 & 0,119 & 0,151 & 0,330 \\
\hline
\end{tabular}

Source: Data that have been processed by SEM AMOS versi 20.

For reliability test in this study with Cronbach's Alpha values that show how well the item points correlate positively with each other. The acceptable Cronbach's Alpha score is 0.6, (Hair et al, 1995 in Ferdinand, 2014). The second test of reliability is to calculate the value of Composite Reliability of each variable. According to Hair et al, (in Ferdinand, 2014) the acceptable Composite Reliability is $\geq 0.70$.

Table 3 - Value of Cronbahc's Alpha (CA) and Composite Reliabilitas (CR)

\begin{tabular}{llll}
\hline Varable & $C A$ & $C R$ & Conclusion \\
\hline Leadership & .886 & 0,73 & Reliable \\
Work Environment & .927 & 0,82 & Reliable \\
Job Satisfaction & .907 & 0,76 & Reliable \\
Organizational Commitment & .946 & 0,87 & Reliable \\
\hline
\end{tabular}

Source: Data that have been processed by SEM.

To know the influence between variables that have been formulated in the hypothesis in the study used path analysis with the help of SEM with software AMOS Version 20 as seen in Table 4. Hypothesis testing is done by looking at the value of critical ratio (CR) and 
p-value value as a result data processing compared to the required statistical constraints. The required critical ratio value is above 1.96 and the required probability value is below 0.05 (Ferdinand, 2014; and Waluyo, 2011).

Table 4 - Result of SEM analysis

\begin{tabular}{|l|l|l|l|l|}
\hline Hypothesis & $\beta$ & CR & $P$ & Conclusion \\
\hline H1: Leadership $\rightarrow$ Job Satisfaction & 0,22 & 2,44 & 0,01 & Significant \\
\hline H2: Work Environment $\rightarrow$ Job Satisfaction & 0,34 & 3,70 & 0,01 & Significant \\
\hline H3: Leadership $\rightarrow$ Organizational Commitment & 0,30 & 3,15 & 0,01 & Significant \\
\hline H4: Work Environment $\rightarrow$ Organizational Commitment & 0,19 & 2,31 & 0,02 & Significant \\
\hline H5: Job Satisfaction $\rightarrow$ Organizational Commitment & 0,35 & 4.14 & 0,01 & Significant \\
\hline H6: Leadership $\rightarrow$ Job Satisfaction $\rightarrow$ Organizational Commitment & $0,22 \times 0,35=0,077$ & Significant \\
\hline H7: Work Environment $\rightarrow$ Job Satisfaction $\rightarrow$ Organizational Commitment & $0,34 \times 0,35=0,119$ & Significant \\
\hline
\end{tabular}

Source: Data that have been processed by SEM AMOS versi 20.

In this study found Leadership, Work environment have a significant and positive effect on job satisfaction and organizational commitment of elementary school teachers in Batukliang subdistrict. Leadership and Work Environment have a significant and positive effect on organizational commitment through satisfaction of teachers of Elementary School in Batukliang Subdistrict.

Hypothesis 1: There is effect of leadership to job satisfaction of Elementary School teacher at Batukliang Subdistrict, which means if the better leadership will be higher satisfaction of Elementary School teacher at Batukliang. The results of this study support research from Muttaqien (2014), where simultaneously and partially leadership has a significant effect on job satisfaction. Research conducted by Plangiten (2013), Junaedi et al., (2013) and Tabitha \& Harjanti (2015), research results show that leadership style affect the employee job satisfaction.

Good leadership is characterized by ability of the principal to describe the work program, the ability to provide clear guidance, to develop freedom of think and expression, the ability of the principal to develop harmonious cooperation, the ability of the principal to solve problems and take the decision, the principal's efforts to develop the ability to assume responsibility and the principal's efforts to utilize supervision as a controlling tool. If it is able to be realized properly then the leadership of the principals of elementary school in Batukliang Subdistrict will be able to provide job satisfaction for teachers of elementary school in the district of Batukliang.

In this study, the teachers of elementary school in Batukliang sub-district who are the respondents on this research are civil servant status, the amount of income received is enough to give satisfaction to the teachers of elementary school in Batukliang Sub-district. But it will be different from non-civil servant teachers or income policy or salary policy is still far from the word worthy or satisfied when compared with the workload given, this is where a fair leader needed. The results of this study not support the research conducted by Rahmi (2013) where transformational leadership has a positive but not significant impact on job satisfaction. The results of this study also not support research by Hidayat (2013) where not significant direct positive effect of leadership on job satisfaction. This means that the leadership is expected to fail to create employee satisfaction.

Hypothesis 2: There is effect of work environment on job satisfaction of elementary school teacher at Batukliang Subdistrict. This means that the more comfortable or supportive work environment, it will increase the work satisfaction of Elementary School teachers in Batukliang District. Conversely, if the work environment is not supportive or uncomfortable then the teacher work satisfaction will also decrease. The results of this study support research by Kurniasari \& Halim (2013) where the results of his research indicate that the work environment has an effect on job satisfaction. Similarly, Plangiten (2013) and Nasution (2013) concluded that the work environment affects employee job satisfaction. Mincu Research (2014) also gives the conclusion that the work environment in an organization affect the job satisfaction. 
The results of research on work environment variables provide responses of respondents who provide a fairly positive response from 10 indicators that reflect the work environment of Teachers Elementary School in Batukliang District with the category quite comfortable. This means that the work environment of Elementary School teachers in Batukliang District is considered quite comfortable. According Luthans (2006), working conditions have an effect on job satisfaction. If the conditions are good (e.g clean, the environment is interesting), individuals will be easier to complete their work. Conversely, if bad working conditions (e.g hot air, noisy environment), individuals will be difficult to complete their work. It is still in the same study that the label is due to the increasing labor diversity of working conditions. Work environment effects on job satisfaction as well as work group effects. If the work environment is good then there will be no problem on job satisfaction, and vice versa if the work environment is bad then it will cause problems of job dissatisfaction. This reinforces Herzberg (1959) opinion as revealed above factors affecting job satisfaction such as working conditions, work environment, subordinate employee relations, and peer relationships.

Hypothesis 3: There is effect of leadership on organizational commitment of elementary school teachers in Batukliang sub-district. The better the principal performs the leadership functions, the better the organizational commitment of the teacher in the organization of the elementary school environment in Batukliang sub-district. The findings of this study support research conducted by Tabitha and Harjanti (2015) in which leadership style has a positive and significant effect on organizational commitment. Research by Hidayat (2013) has a significant direct and positive influence of leadership on organizational commitment. Research conducted by Zaleha et al., (2013) in Islamic banks states that a leader will affect employee motivation that ultimately leads to organizational growth productivity. Therefore, with a good and comfortable culture within an organization, employees are likely to perform better and have stronger commitment to the organization. Similarly, research conducted by Santoso (2014) concludes that leadership style has significant influence on organizational commitment, Rahmi (2013) and Retnaningsih (2007) transformational leadership have a positive and significant effect on organizational commitment. The results of this study differ from those of Junaedi et al., (2013) where their results show that leadership has no significant effect on organizational commitment.

Hypothesis 4: There is effect of work environment to the organizational commitment of elementary school teachers in Batukliang sub-district. The more comfortable working environment will be the better organizational commitment of employees in an organization in this case is the elementary school teacher as the District Batukliang. The findings of this study supporting research conducted by Rustini (2015) suggest there is a positive influence of the work environment on commitment. McGuire and McLaren (2009) have a strong positive relationship between the physical environment and employee commitment. Similarly, the results of previous research conducted by Saputra (2013), Kurniasari and Halim (2013) where the work environment is measured through workspace design indicator, job equipment design, lighting, temperature and air regulation, noise, leadership style boss, which is bad, and giving authority in job description and decision making have an effect on organizational commitment. This means the work environment is one of the factors that determine the organizational commitment of employees.

Hypothesis 5: There is effect of job satisfaction on organizational commitment of elementary school teacher in Batukliang sub-district. The more satisfied a teacher will be to increase the organizational commitment of the teacher will increase towards the organization where they work. The results of this study support previous research conducted by Karim and Rehman (2012), found job satisfaction significantly affects organizational commitment. The results of this study also supports research by Saputra (2013) with the findings of his research that job satisfaction has a significant effect on organizational commitment in which job satisfaction has a dominant influence. The study also supports the research of Novriyadhi and Riana (2015), Putra and Wibawa (2015), Wirakusuma and Sintaasih (2015), Tabitha and Harjanti (2015), Kurniasari and Halim (2013), Junaedi et al., (2013), Retnaningsih (2007), Muhadi (2007), Santoso (2014) and Parwita (2013) with the results of the study concluded 
that job satisfaction has an effect on organizational commitment. The research of Manuel and Rahyuda (2015) shows that affective commitment, commitment calculative, and normative commitment have a mediating role between the effect of job satisfaction on turnover intention. However, it does not support Rahmi (2013) where job satisfaction has a positive but insignificant effect on organizational commitment.

Hypothesis 6: The results showed that leadership has a significant effect on the organizational commitment of elementary school teachers in Batukliang sub-district through job satisfaction as a mediation variable. This implies that the better the leadership run can improve job satisfaction for teachers. If teachers are satisfied then the teacher's commitment to the organization will increase. The findings of this study are supported by research conducted by Tabitha and Harjanti (2015) where the leadership style has a positive and significant impact on organizational commitment either directly or indirectly through job satisfaction. Research by Santoso (2014) concluded that job satisfaction mediates the influence of leadership style on organizational commitment. Tabitha and Harjanti (2015) provide research conclusions that job satisfaction mediates the influence between leadership styles on organizational commitment. However, the results of this study do not support Hidayat (2013) who find job satisfaction can not mediate the influence between leadership on organizational commitment.

Hypothesis 7: The Effect of Work Environment on Organizational Commitment through Job Satisfaction. The findings indicate that the work environment has a significant effect on the organizational commitment of elementary school teachers in Batukliang sub-district through job satisfaction as intervening variable. This means satisfaction is able to mediate the relationship of influence between the work environments with organizational commitment. This means that the more supportive working environment tends to increase teachers job satisfaction. If teachers are satisfied then the teachers commitment to the organization will increase. Saputra (2013) in his research found that the work environment had an effect on organizational commitment. Conducive working environment, clean and comfortable can give satisfaction for every employee, which in akihirnya tendency of employees to commit in organization will be high. Conversely, if the work environment does not support such as not conducive, the equipment is all short and limited, it is unlikely the employee will feel satisfied. If employees feel satisfied then the indication that the employee to commit to the organization is getting smaller and can potentially turn over.

\section{CONCLUSION}

Both leadership and working environment have a significant positive effect on job satisfaction and organizational commitment of elementary school teacher in Batukliang subdistrict. Leadership and working environment positively influence the organizational commitment and the satisfaction of teachers at elementary school Batukliang District. In theory, there are many variables that can alter organizational satisfaction and commitment. But the focus on this research is whether organizational satisfaction and commitment can be influenced by leadership and working environment either directly or indirectly so that the findings can contribute to the development of the institution especially Human Resource Management and can be a scientific reference for the parties concerned. Leadership can affect work satisfaction and organizational commitment of teachers. Therefore, it is expected that the principal of elementary school in Batukliang sub-district to implement an effective leadership pattern by continuously improving the ability to carry out leadership functions well through various policies that favor teachers' well-being such as giving rewards for outstanding teachers thus that teachers are more motivated in improving teaching quality and performance.

Working environment as a factor that can affect teacher job satisfaction so that teachers become more committed to the organization. Therefore it is expected that the school should pay more attention to the working environment of teachers by providing proper facilities that can support the performance of teachers thus teachers are more comfortable in the process of teaching. Whereas, teachers of elementary school in Batukliang sub-district 
are expected to continue improving their performance, reduce procrastinating and absenteeism level because a teacher is the role model for students should give a decent example in the school. For the Government especially the District Batukliang to continue to pay attention to the condition of physical facilities and infrastructure SD Negeri District Batukliang, thus the teaching and learning activities for teachers and students more comfortable and safe. And they expected to continue to improve the well-being of teachers by allocating the appropriate, and fair salary budget for teachers.

This study has limitations because it only focuses on leadership and work environment, on job satisfaction and organizational commitment with the object of research that is the status of civil servant teachers in educational institutions. Therefore, in the future research, we can examine the variables in this study by adding some other variables such as individual characteristics, compensation, work performance with different research objects, samples and analytical tools to obtain more diverse and comparable output.

\section{REFERENCES}

1. Akhtar, J. (2014). Impact of Work Environment, Salary Package and Employees Perception on Organizational Commitment: A study of Small \& Medium Enterprises (SMEs) of Pakistan. International Journal of Academic Research in Business and Social Sciences, 4 (8), 147-165. doi:10.6007/IJARBSS/v4-i8/1081

2. Brenninkmeyer, L. D., \& Spillane. (2008). Problem-solving processes of expert and typical school principals: A quantitative look. School Leadership and Management, 28 (5), 435-468. http://dx.doi.org/10.1080/13632430802517209

3. Ferdinand, A. (2014). Metode Penelitian Manajemen. Universitas Diponegoro. Semarang.

4. Gholi pour, A. (2012). Management of Organizational Behavior. Samt publication. Tehran.

5. Hidayat, R. (2013). Pengaruh Kepemimpinan terhadap Komunikasi, Kepuasan Kerja, dan Komitmen Organisasi pada Industri Perbankan. Makara Seri Sosial Humaniora, 17, (1), 19-32.

6. Hopkins, D. (2001a). School improvement for real. London: Falmer Press. http://dx.doi.org/10.4324/9780203165799

7. Hopkins, D. (2001b). Meeting the challenge: an improvement guide for schools facing challenging circumstances. London: DfES.

8. Ivancevich, J.M., Konopaske, R., \& Matteson, M. T. (2007). Perilaku dan Manajemen Organisasi, Jakarta: Penerbit Erlangga.

9. Junaedi, D., Swasto, B. \& Utami, H.N. (2013). Pengaruh Gaya Kepemimpinan, Keselamatan dan Kesehatan Kerja, Kepuasan Kerja terhadap Komitmen Organisasional (Studi pada Karyawan PG. Kebet Baru Malang). Jurnal Profit, 7 (1), 127-136.

10. Karim, F., \& Rehman, O. (2012). Impact of Job Satisfaction, Perceived Organizational Justice and Employee Empowerment on Organizational Commitment in SemiGovernment Organizations of Pakistan. Journal of Business Studies Quarterly, 3 (4), 92104.

11. Kurniasari, D., \& Halim, A. (2013). Pengaruh Lingkungan Kerja dan Iklim Organisasi terhadap Komitmen Organisasi Melalui Kepuasan Kerja Karyawan pada Dinas Pasar Unit Pasar Tanjung Kabupaten Jember. Jurnal IImu Ekonomi, 8 (2), 273-284.

12. Luthans, F. (2006). Perilaku Organisasi, Edisi Sepuluh, Yogyakarta: Penerbit Andi.

13. Manuel, G.P.EB., \& Rahyuda, A.G. (2015). Pengaruh Kepuasan Kerja, Komitmen Afektif, Komitmen Kalkulatif, dan Komitmen Normatif terhadap Turnover Intention di Ayodya Resort Bali. E-Jurnal Manajemen Unud, 4 (8), 2243-2268.

14. McGuire, D. \& McLaren, L. (2009). The Impact of Physical Environment on Employee Commitment in Call Centres: The Mediating Role of Employee Well-Being. Team Performance Management, 15 (1), 35-48. 
15. Mincu, C.L. (2015). The Impact of Good Place Work on Organizational Attitudes: Job Satisfaction and Trust in Organization. Procedia-Social and Behavioral Sciences, 187, 685-689.

16. Muhadi. (2007). Analisis Pengaruh Kepuasan Kerja terhadap Komitmen Organisasional dalam Mempengaruhi Kinerja Karyawan (Studi pada Karyawan Administrasi Univeristas Diponegoro). Tesis, Program Pascasarjana Universitas Diponegoro.

17. Muttaqien, F. (2014). Pengaruh Kepemimpinan dan Kompensasi terhadap Kepuasan Kerja Karyawan Outsourcing pada PT. BRI (Persero), Tbk. Cabang Lumajang. Junal WIGA, 4 (1), 19-33.

18. Nasution, W.A. (2013). Pengaruh Kompensasi dan Lingkungan Kerja terhadap Kepuasan Kerja Karyawan pada PT. Karya Deli Stelindo Medan. Jurnal Manajemen Bisnis STIE IBBI, 20 (2), 1-11.

19. Novriyadhi, R. O., \& Riana, G. (2015). Pengaruh Keadilan Organisasional terhadap Kepuasan Kerja dan Komitmen Organisasi pada PT. Astra International Auto 2000 Denpasar. E-Jurnal Manajemen Unud, 4 (6), 1753-1770.

20. Parwita, G.B.S. (2013). Pengaruh Kepuasan Kerja terhadap Komitmen Organisasi dan Disiplin Kerja (Studi pada Dosen Yayasan Universitas Mahasaraswati Denpasar). Tesis Program Pascasarjana Universitas Udayana Denpasar.

21. Plangiten, P. (2013). Gaya Kepemimpinan dan Lingkungan Kerja Pengaruhnya terhadap Kepuasan Kerja Karyawan pada PT. Pos Indonesia (Persero) Manado. Jurnal EMBA, 1 (4), 2155-2166.

22. Putra, I G.A.G.E.M., \& Wibawa, I M. A. (2015). Pengaruh Kepuasan Kerja terhadap Turnover Intention dengan Komitmen Organisasi sebagai Variabel Intervening Pada PT. Autobagus Rent Car Bali. E-Jurnal Manajemen Unud, 4 (4), 1100-1118.

23. Rahmi, B.M. (2013). Pengaruh KepemimpinanTransformasional terhadap Organizational Citizenship Behavior dan Komitmen Organisasional dengan Mediasi Kepuasan Kerja (Studi pada Guru Tetap SMA Negeri di Kabupaten Lombok Timur). Tesis Program Pascasarjana Universitas Udayana.

24. Retnaningsih, S. (2007). Analisis Pengaruh Keadilan Kompensasi, Peran Kepemimpinan, dan Kepuasan Kerja terhadap Komitmen Organisasi dalam Meningkatkan Kinerja Karyawan (Studi Kasus: pada Sentral Pengolahan Pos Semarang). Tesis Program Pascasarjana MM Universitas Diponegoro.

25. Rivai, V\& Mulyadi, D. (2010). Kepemimpinan dan Perilaku Organisasi, Jakarta: Rajagrafindo Persada.

26. Robbins, S.P., \& Judge T. A. (2008). Perilaku Organisasi: Organizational Behavior Edisi 12. Buku 1. Jakarta: Salemba Empat.

27. Rustini, N.K.A. (2015). Pengaruh Kompensasi dan Lingkungan Kerja pada Komitmen Organisasi dan Implikasinya pada Kinerja Pengelola Anggaran (Studi Empiris pada Satuan Kerja Perangkat Daerah Pemerintah Kabupaten Tabanan). Tesis Program Pascasarjana Universitas Udayana.

28. Santoso, M.H. (2014). Pengaruh Gaya Kepemimpinan terhadap Komitmen Organisasional dengan Kepuasan Kerja Sebagai Variabel Intevening pada PT. Mitra Cimalati di Cilacap Agora, 2 (1).

29. Saputra, A.P. (2013). Pengaruh Lingkungan dan Kepuasan Kerja Karyawan Terhadap Komitmen Organisasional (Studi pada PT. Industri Sandang Nusantara (ISN) Unit Patal Lawang Malang). Jurnal Ilmiah Mahasiswa FEB, 2 (2).

30. Sergiovanni, T. J. (1995). The head leachership: A reflective practice perspective. Boston: Allyn and Bacon.

31. Sopiah. (2008). Perilaku Organisasional. Yogyakarta: Penerbit Andi.

32. Sutrisno, E. (2009). Manajemen Sumber Daya Manusia. Jakarta : Kencana.

33. Tabitha, J. \& Harjanti, D. (2015). Pengaruh Gaya Kepemimpinan terhadap Komitmen Organisasional dengan Kepuasan Karyawan Sebagai Mediator pada PT Young Multi Sarana' AGORA, 3 (2), 224-230. 
34. Waluyo, M. (2011). Panduandan Aplikasi Structural Equation Modelling: untuk Aplikasi Model dalam Penelitian Teknik Industri, Psikologi, Sosial dan Manajemen, Jakarta: Indeks.

35. West, M., Jackson, D., Harris, A., \& Hopkins, D. (2000). Leadership for school improvement. in K. Riley \& K. Seashore-Louis (eds.) Leadership for change. London: Routledge, 35-47.

36. Wibowo. (2010). Manajemen Kinerja, Jakarta: Rajagrafindo Persada.

37. Wirakusuma, I. N., \& Sintaasih, D. K. (2015). Peran Status Kepegawaian dalam Memoderasi Pengaruh Kepuasan Kerja terhadap Komitmen Organisasional Pegawai Dinas Perhubungan Informasi dan Komunikasi Provinsi Bali. E-Jurnal Manajemen Unud, 4 (3), 795-812.

38. Wirawan. (2013). Kepemimpinan: Teori, Psikologi, Perilaku Organisasi, Aplikasi dan Penelitian, Jakarta: Rajagrafindo Persada.

39. Zaleha, S, AR., Aizat, M, AM., \& Quoquab, F.(2013). Leadeship and Organizational Commitment in the Islamic Banking Context: The Role of Organizational Culture as a Mediator. American Journal of Economics, 3 (5C), 171-176 